\title{
GENOTOXIC EFFECT OF PESTICIDES ON HUMAN LEUKOCYTE CULTURE: A REVIEW
}

\author{
DEBANJANA MITRA, ABILASH VG* \\ Department of Biomedical Sciences, School of Bio Sciences and Technology, VIT University, Vellore, Tamil Nadu, India. \\ Email: abilash.vg@vit.ac.in
}

Received: 25 May 2016, Revised and Accepted: 28 May 2016

\section{ABSTRACT}

Pesticides have long been in use in the agricultural fields, plantation firms, and also for household purposes. However, there are a considerable number of studies which prove the detrimental effects of the pesticides that include biochemical, histopathological, and genetic effects. The aim of this article is to present a review on the effects of pesticides on leukocytes which have been analyzed through various assays including chromosome analysis, cytokinesis-block micronuclei assay, comet assay, semen, and sperm analysis. The studies have shown organophosphates and carbamates to be the most potential sources of genotoxicity and the individuals exposed to these groups of pesticides are relatively much more prone to genotoxicity. Further investigation on molecular mechanism by which the pesticides affect the genome of cells needs to be carried out.

Keywords: Pesticides, Genotoxicity, Chromosome analysis, Cytokinesis-block micronucleus cytome assay, Semen analysis.

(C) 2016 The Authors. Published by Innovare Academic Sciences Pvt Ltd. This is an open access article under the CC BY license (http://creativecommons org/licenses/by/4. 0/) DOI: http://dx.doi.org/10.22159/ajpcr.2016.v9i5.13080

\section{INTRODUCTION}

Pesticides, herbicides, fungicides, and insecticides have long been in use in agricultural practices as they are effective and quick [1]. However, the detrimental effects of these chemicals on human health are prominent as seen on the immediate workers who get extensively exposed. In general, the agricultural workers of the developing countries are more exposed prolonged because these countries rely on manual spraying. There are also long-term effects of oral ingestion along with the dermal exposure or respiratory inhalation. Studies reveal that the chemical pesticides are mostly responsible for causing mutagenic and carcinogenic effects. The broad classes of pesticides and insecticides used mostly include organophosphate, carbamate, pyrethroid, organochloride, and sulfonylurea. With the increase in research conducted on these chemicals, there are a host of pesticides that are getting banned in various countries. This article is a review on the genotoxic effects of all such classes of pesticides and their formulations derivatives on human peripheral leukocytes. There are a hosts of assays and experiments done to analyze the cytotoxic and genotoxic aspects of chemicals on the human lymphocytes which include chromosomal aberration frequency analysis, sister chromatid exchange, cell cycle kinetics, comet assay, and micronuclei assay [2].

\section{Organophosphates}

These are the most commonly used group of pesticides and have been broadly studied for genotoxocity [3]. There were studies done with a number of organophosphates which comprised azodrin, diazinon, dichlofenthion, dimethoate, dursban, ethion, fenthion, malathion, methylparathion, parathion, phorate, phosdrin, R-1303, and viozene [2]. Cell line proliferation, sister chromatid exchange, metabolic activation assays were performed using different concentration range of the chemical which was $0.02,0.2,2$, and $20 \mu \mathrm{g} / \mu \mathrm{l}$. Low doses did not have significant effects on the cell proliferative rate. The cultures treated with $2 \mu \mathrm{g} / \mu \mathrm{l}$ showed prominent inhibition of cell proliferation ranging from $31 \%$ of growth in cultures treated with azodrin to $67 \%$ of growth in cultures treated with diazonin. The inhibition increased further with an increase in concentration to $20 \mu \mathrm{g} / \mu \mathrm{l}$ which showed $11 \%$ of growth for azodrin treated cultures, having the lowest growth and $53 \%$ of growth in cells treated with malathion having the highest. These data were supported strongly by the mitotic index calculation done on the cultures. Azodrin (at high concentrations of 2 and $20 \mu \mathrm{g} / \mu \mathrm{l})$ showed the most pronounced inhibitory effect on mitosis with $2 \pm 11$ cells in mitotic stage out of 100 cells scored against $20 \pm 4$ in the control condition. Phosdrin had also shown a similarly significant effect at $0.2 \mu \mathrm{g} / \mu \mathrm{l}$ with $5 \pm 1$. Sister chromatid exchange analysis showed marked increase in its frequency for malathion, parathion, and R-1303 treated cells for $0.2 \mu \mathrm{g} / \mu \mathrm{l}$ concentration whereas for 2 and $20 \mu \mathrm{g} / \mu \mathrm{l}$ dose treated cells all treatments showed elevation excepting ethion, fenthion, and diazinon.

Acephate, a widely used pesticide in India, has lethal concentration $50\left(\mathrm{LC}_{50}\right)$ found to be $45 \mu \mathrm{m}$ as determined by trypan blue dye exclusion method. Peripheral human leukocytes [3] treatments with sub-LCs of these pesticides have shown to induce satellite associations, chromatid breaks, and chromatid gaps as the frequent types of chromosomal aberrations. Comet assay performed supported these results and revealed an elevated number of DNA single strand breaks in the cells treated with the same sub-LCs. The results fell into the statistically significant area carried out by t-test with $\mathrm{p}<0.05$. Cell viability was seen to be decreasing with increasing dose of the pesticide indicating dose-dependent genotoxicity as it showed $100 \%$ mortality at $70 \mu \mathrm{m}$ concentration of the compound. Chromosomal aberration analysis showed 8\% increase in satellite association, 7\% increase in chromatid breaks, and $9 \%$ increase in chromatid gap against the normal controls. The comet assay results showed an increase in the tail length from 0.1 to $0.95 \mu \mathrm{m}$ with the increase in acephate concentration level from 0 to $7 \mu \mathrm{m}$.

Chromosomal aberration, sister chromatid exchange, mitotic index analysis, and glucose-6-phosphate dehydrogenase enzyme activity were analyzed for four widely used organophosphate pesticides which are glyphosate, vinclozolin, atrazine, and DPX-E9636 [4]. Each of the compounds showed dose-dependent increase in cytotoxicity as suggested by the increase in the percentage of aberrant cell and sister chromatid exchange. Furthermore, there was a significant reduction in mitotic index and cell proliferative index at the highest concentration level of the four compounds. Profenofos another extensively used organophosphate has $\mathrm{LC}_{50}$ as $3.5 \mu \mathrm{m}$ and has shown increase in satellite association (12-14\%), chromatid breaks (8-15\%), and chromatid gaps (4-9\%) with increase in concentrations [5].

\section{Organochlorines}

Dicamba is an organochloride, a methoxybenzoic acid which is commercially used in various formulations such as Oracle, Vanquish, and Benvel. Dicamba and its derivative Banvel have been tested on human leukocyte cells from a dose range of $10-500 \mu \mathrm{g} / \mu \mathrm{l}[6]$. At 200 and 
$500 \mu \mathrm{g} / \mu \mathrm{l}$, respectively for Dicamba and Banvel, there was significant increase in sister chromatid exchange and reduction in cell kinetics, measured through cell proliferative index and mitotic activity.

Another study carried out with two organochlorides namely alachlor, and maleic hydrazides showed elevation in the chromosomal aberration frequency, sister chromatid exchange as well as micronuclei [7]. However, the optimum concentrations of these two compounds were found to be different. The optimum concentration beyond which there was significant increase in the genotoxicity was found to be $1 \mu \mathrm{g} / \mathrm{ml}$ for alachlor, and that for maleic hydrazide was found to $100 \mu \mathrm{g} / \mathrm{ml}$. In addition, however, alachlor was found to be clastogenic only at the highest concentration $20 \mu \mathrm{g} / \mathrm{ml}$ based on the number of chromosomal aberrations and micronuclei obtained from the respective assays performed.

A study involving 41 workers exposed to carbon tetrachloride, perchloroethylene, and hexachlorobenzene (HCB) clearly indicated a prominent rise in the frequency of micronuclei in the human lymphocyte cell cultures of the workers assessed by cytokinesis-block micronuclei assay [8].

Micronuclei tests performed on human peripheral leukocyte cells with dichlorobischlorophenylethylene a metabolite of dichlorobiphenyltrichloroetane and HCB indicated that $80 \mathrm{mM}$ is the optimum concentration to cause micronuclei formation at genotoxic level [9]. The compound was tested in a concentration gradient ranging from 10 to $80 \mathrm{mM}$. However, HCB did not produce much of a significant genotoxic result which was carried out in the concentration range from 0.005 to $0.1 \mathrm{mM}$.

\section{Carbamates}

Amitrole or aminotriazole, belonging to the carbamate category of pesticide have shown frequent chromosomal aberration in peripheral blood cultures of workers exposed to the compound. In a consented experiment conducted on volunteers, a $100 \mathrm{mg}$ of amitrole was administered orally given as a single dose. Thyroid iodine uptake was seen to be inhibited in the volunteers after $24 \mathrm{hrs}$ of ingestion. Deaths due to cancer have been reported of workers exposed to amitrole and chlorophenoxy herbicides for 45 days or more. Subsequently, it has been banned in the United States [10].

There have been similar studies conducted with zineb, zinc containing dithiocarbamate, and its commercial formulation named azzurro. Analysis of the frequency of chromosomal aberration, sister chromatid exchange, and cell cycle progression assays was conducted on human peripheral lymphocytes [11]. At 50 and $100 \mu \mathrm{g} / \mu \mathrm{l}$ concentrations of this fungicide, there were significant increase in sister chromatid exchange and corresponding decrease in cell cycle progression and proliferative rate index at those respective doses. Aldicarb and cytophosphane have been seen to increase sister chromatid exchange and decrease mitotic progression of the human lymphocyte cells $[12,13]$.

A collective study done to compare the genotoxic effect of a mixture of carbamates that involved carbosulfan, ethyl methanesulfonate, and ethyl carbamate showed that a mixture of carbosulfan and ethyl carbamate each administered at $2 \mathrm{mM}$ concentrations did not bring about much of aberrations in chromosome analysis neither the frequency of abnormal cells were high in the human leukocytes [14]. However, when the concentration of the mixture was raised to $4 \mathrm{mM}$ and $8 \mathrm{mM}$ subsequently, the percentage of abnormal cells and chromosomal aberration increased with $24 \mathrm{hrs}$ of incubation in all the cases. However, there were not any synergism seen in the different concentration mixtures of carbosulfon and ethyl carbamate excepting the mixture at $0.1 \mathrm{mM}$ concentration of carbosulfan and $8 \mathrm{mM}$ concentration of ethyl carbamate. Furthermore, there was a synergistic increase in Mitotic Index seen in the human leukocyte cultures at a mixture of $0.025 \mathrm{mM}$ and $0.5 \mu \mathrm{m}$ carbosulfan with $200 \mathrm{mM}$ of ethyl carbamate. Whereas Mitotic Index decreased when a mixture of 0.025 and $0.1 \mathrm{mM}$ of carbosulfan was given with $4 \mathrm{mM}$ of ethyl carbamate. In addition, there was a synergism seen in the cultures treated with a combination of carbamate and ethyl methanesulfonate at a concentration mixture of $0.5 \mu \mathrm{m}$ of each of the compound which increased both the frequency of aberrations in chromosomes and abnormal cells. However, no synergism was observed in the Mitotic Index of the leukocytes at such concentration mixtures. Chromatid breaks, isochromatid breaks, and chromatid exchange were the most frequent aberrations seen in these treatments.

\section{Pyrethroid}

These classes of insecticides comprise mainly of the household insecticides, and they are synthetic version of the compound present in the extract of chrysanthemum flowers. Cypermethrin, one of the most commonly used pyrethroid have not been categorized as highly dangerous as suggested by some of the studies where they have not been seen to induce chromosomal aberrations and sister chromatid exchange $[15,16]$. Fenvalerate has been seen to increase both. In addition, both of them have been found to reduce cell cycle kinetics by decreasing cell proliferative index and cell cycle progression at the concentration level of $10 \mu \mathrm{g} / \mathrm{ml}$.

Permethrin, another pyrethroid which is a known neurotoxin have been tested for clastogenic effect. A range of concentration from 50 to $200 \mu \mathrm{g} / \mathrm{ml}$ were used, and the compound showed clastogenic effects as the frequency of chromosomal aberrations increased with the increase in its concentration [17].

A comparative study was performed using five pyrethroid pesticides, namely, cypermethrin, deltamethrin, fenpropathrin, fenvalerate, and permethrin, and they were assessed on the basis of micronuclei

Table 1: Data on workers working in chemical plants are compiled

\begin{tabular}{|c|c|c|c|c|}
\hline $\begin{array}{l}\text { Chemical plant workers-exposed } \\
\text { population/control population }\end{array}$ & $\begin{array}{l}\text { Exposure to the } \\
\text { pesticide }\end{array}$ & $\begin{array}{l}\text { Duration of } \\
\text { exposure (in years) }\end{array}$ & $\begin{array}{l}\text { Cytogenetic } \\
\text { biomarker assessed }\end{array}$ & Result \\
\hline $45 / 31[24]$ & $\begin{array}{l}\text { Novozir Mn80 (fungicide } \\
\text { containing mancozeb) }\end{array}$ & Up to 2 & $\begin{array}{l}\text { Chromosomal } \\
\text { aberration sister } \\
\text { chromatid exchange }\end{array}$ & $\begin{array}{l}\text { Positive }(+1.82) \\
\text { Positive }(+1.16)\end{array}$ \\
\hline $\begin{array}{l}15 / 50,10 \text { formulators, five } \\
\text { packers [25] }\end{array}$ & $\begin{array}{l}\text { Azynphos methyl, } \\
\text { methyl parathion, } \\
\text { malathion, dimethoate }\end{array}$ & Not available & $\begin{array}{l}\text { Sister chromatid } \\
\text { exchange }\end{array}$ & Positive $(+1.22)$ \\
\hline $19 / 36[26]$ & $2,4,5-T, 2,4-D$ & $10-25$ & $\begin{array}{l}\text { Chromosomal } \\
\text { aberration }\end{array}$ & Positive $(+2.06)$ \\
\hline $20 / 20$ [27] & $\begin{array}{l}\text { Pesticide mixture of } \\
\text { cyanazine, malathion, } \\
\text { 2,4-D, alachlor, atrazine }\end{array}$ & $\begin{array}{l}\text { 6-30 (sample collected } \\
8 \text { months after subjects } \\
\text { were exposed) }\end{array}$ & $\begin{array}{l}\text { Chromosomal } \\
\text { aberration }\end{array}$ & Positive $(+6.11)$ \\
\hline $135 / 111[28]$ & Organophosp-hates & $3-24$ & $\begin{array}{l}\text { Sister chromatid } \\
\text { exchange }\end{array}$ & $\begin{array}{l}\text { Positive }(+1.86 \\
\text { smokers) (+1.70 } \\
\text { non-smokers) }\end{array}$ \\
\hline
\end{tabular}


Table 2: Data on workers involved in pesticide spraying and exposed to single pesticide are compiled

\begin{tabular}{|c|c|c|c|c|}
\hline $\begin{array}{l}\text { Pesticide sprayers-exposed } \\
\text { population/control population }\end{array}$ & Exposure to the pesticide & $\begin{array}{l}\text { Duration of } \\
\text { exposure } \\
\text { (in years) }\end{array}$ & $\begin{array}{l}\text { Cytogenetic biomarker } \\
\text { assessed }\end{array}$ & Result \\
\hline $36 / 15$ [29] & Workers in forestry: 2,4-D,MCPA & Not available & Sister chromatid exchange & Negative \\
\hline \multirow[t]{2}{*}{$61 / 42[30]$} & \multirow{2}{*}{$\begin{array}{l}\text { Workers in papaya plantations exposed } \\
\text { to ethylene dibromide }\end{array}$} & \multirow[t]{2}{*}{5} & Chromosomal aberration & Negative \\
\hline & & & Sister chromatid exchange & Negative \\
\hline $20 / 17[31]$ & Workers in forestry: 2,4-D,MCPA & 6-28 days & Chromosomal aberration & Negative \\
\hline $25 / 25[32]$ & $\begin{array}{l}\text { Fumigators (in open field): Phosphine, } \\
\text { other pesticides }\end{array}$ & $\begin{array}{l}\text { Discontinuous } \\
\text { use in } 8 \text { months }\end{array}$ & Chromosomal aberration & Positive $(+3.60)$ \\
\hline $20 / 26[33]$ & Fumigators (in open field): Phosphine & $\begin{array}{l}\text { Discontinuous } \\
\text { use in } 8 \text { months }\end{array}$ & Chromosomal aberration & Positive $(+3.32)$ \\
\hline $35 / 21[34]$ & Fumigators: Phosphine & Not available & Micronuclei & Negative \\
\hline $38 / 16[35]$ & $\begin{array}{l}\text { Eradication of Medfly program: } \\
\text { malathion }\end{array}$ & Not available & Micronuclei & Negative \\
\hline $31 / 31[36]$ & $\begin{array}{l}\text { Fungicide sprayers } \\
\text { spraying (dithiocarbamate) ethylenbis }\end{array}$ & Not available & Chromosomal aberration & Positive $(+1.33)$ \\
\hline $13 / 30[36]$ & Farmers growing tomatoes & 2 & Chromosomal aberration & Negative \\
\hline $32 / 27[37]$ & Fumigators applying methylbromide & $0.3-22$ & Micronuclei & Negative \\
\hline $12 / 10[38]$ & Sprayers of 2,4-D & $\begin{array}{l}\text { Discontinuity } \\
\text { in exposure }\end{array}$ & Micronuclei & Negative \\
\hline
\end{tabular}

MCPA: 2-methyl-4-chlorophenoxyacetic acid

Table 3: Data on workers involved in pesticide spraying and exposed to a mixture of pesticide are compiled

\begin{tabular}{|c|c|c|c|c|}
\hline $\begin{array}{l}\text { Pesticide sprayers-exposed } \\
\text { population/control } \\
\text { population }\end{array}$ & Exposure to the pesticide & $\begin{array}{l}\text { Duration of } \\
\text { exposure } \\
\text { (in years) }\end{array}$ & $\begin{array}{l}\text { Cytogenetic } \\
\text { biomarker } \\
\text { assessed }\end{array}$ & Result \\
\hline $80 / 25$ [39] & $\begin{array}{l}\text { Mixture of the following pesticides: Carbamates, } \\
\text { organochlorines, heterocyclic compounds, } \\
\text { dithiocarbamates, phenoxy-acetic acids, } \\
\text { nitro-compounds, pyrethroids, phthalimides, } \\
\text { copper and sulphur containing chemicals }\end{array}$ & 1 to $<15$ & $\begin{array}{l}\text { Chromosomal } \\
\text { aberration }\end{array}$ & Positive $(+2.67$ to +3.91$)$ \\
\hline $15 / 15[40]$ & $\begin{array}{l}\text { Workers in vineyards: DDT, copper sulfate, } \\
\text { dieldrin, metasystox dithane, lindane, quinalfos } \\
\text { dichlorvos }\end{array}$ & $6-12$ & $\begin{array}{l}\text { Chromosomal } \\
\text { aberration }\end{array}$ & Positive $(+2.72$ to +3.92$)$ \\
\hline $55 / 61[41]$ & $\begin{array}{l}\text { Workers of greenhouses: } \\
\text { Insecticides (organophosphates, carbamates,); } \\
\text { fungicides, acaricides, pyrethroid }\end{array}$ & $3-15$ & $\begin{array}{l}\text { Chromosomal } \\
\text { aberration }\end{array}$ & Positive $(+1.19$ to 1.55$)$ \\
\hline $27 / 30[30]$ & $\begin{array}{l}\text { Workers of vegetable garden: BHC, parathion, } \\
\text { urea, dimethoate, malathion, gromor, } \\
\text { fenitrothion, DDT }\end{array}$ & $5-40$ & $\begin{array}{l}\text { Chromosomal } \\
\text { aberration } \\
\text { Sister chromatid } \\
\text { exchange }\end{array}$ & $\begin{array}{l}\text { Positive }(+1.73-2.04) \\
\text { Positive }(+1.44-1.53)\end{array}$ \\
\hline
\end{tabular}

BHC: Benzene hexachloride, DDT: Dichlora diphenyl-trychloroethane

assays on whole blood as well as human leukocytes [18]. All of the five pesticides showed dose-dependent cytotoxicity with fenpropathrin proving to be the most cytotoxic of them all. In this study, nuclear division index and cytokinesis-block proliferation index were determined which supported the results yielded by the micronuclei assays and also included the trinucleated and tetranucleated cells. Out of all, cypermethrin and fenpropathr in showed the maximum number of micronuclei formation in the whole blood cells, and deltamethrin showed an elevation in the same in isolated human leukocytes. Permethrin and fenvalerate gave the least toxic results out of all due to the least number of micronuclei produced. This study suggested that pyrethroid pesticides have less cytotoxic and genotoxic effects on human lymphocytes.

There were studies examining 12 workers exposed to fenvalerate and 30 donor control groups [19]. Fluorescence in situ hybridization technique was performed on the sperm samples provided by the volunteers, the results of which revealed significant increase in aneuploidy in the exposed workers and also a rise in the number of sex chromosome trisomies found to be $0.742 \pm 0.131 \%$ against the control group that showed $0.386 \pm 0.140 \%$. The frequency of chromosome 18 trisomies was higher $0.326 \pm 0.069 \%$ against the control reading which was $0.124 \pm 0.068 \%$.

\section{COMPARATIVE ANALYSIS}

A comparative study on organophosphates such as dimethoate, chlorpyrifos, monocrotophos, and organochloride like endosulfan was carried out in one of the studies which revealed endosulfan and monocrotophos to be highly cytotoxic whereas dimethoate is least toxic comparatively [20]. Monocrotophos being an acetylcholinesterase inhibitor has lethal dose 50 value of $14 \mathrm{mg} / \mathrm{kg}$ body weight for oral ingestion and $112 \mathrm{mg} / \mathrm{kg}$ body weight for dermal contact in mammals. Endosulfan is a benzodioxathiepin is a proved endocrine toxic and also causes deformation in male and female genitalia. Dimethoate is an acetylcholinesterase which has a rapid metabolic half-life, and $76-100 \%$ is excreted within 24 hrs of ingestion. Trypan blue dye exclusion assay conducted to check for cell viability showed very low $\mathrm{LC}_{50}$ value of monocrotophos of $0.72 \pm 0.01 \mathrm{mg} / \mathrm{ml}$ and endosulfan with $0.73 \pm 0.001$ indicating their high toxicity. Compared to that, dimethoate is less toxic with $\mathrm{LC}_{50}$ value of $6.92 \pm 0.3 \mathrm{mg} / \mathrm{ml}$ and chlorpyriphos had a moderate vale of $1.74 \pm 0.04 \mathrm{mg} / \mathrm{ml}$. The results were consolidated with 
Table 4: Data on agricultural workers involved in agriculture works are compiled

\begin{tabular}{|c|c|c|c|c|}
\hline $\begin{array}{l}\text { Pesticide sprayers-exposed } \\
\text { population/control population }\end{array}$ & Exposure to the pesticide & $\begin{array}{l}\text { Duration of } \\
\text { exposure } \\
\text { (in years) }\end{array}$ & $\begin{array}{l}\text { Cytogenetic } \\
\text { biomarker } \\
\text { assessed }\end{array}$ & Result \\
\hline $10 / 9[42]$ & $\begin{array}{l}\text { 2,4-D, MCPA, MCPP, diquat, } \\
\text { dithiocarbamates }\end{array}$ & $2-30$ & $\begin{array}{l}\text { Chromosomal } \\
\text { aberration }\end{array}$ & Negative \\
\hline $94 / 77[43]$ & $\begin{array}{l}\text { Carbamates, ureics, triazines, } \\
\text { organophosphates, organochlorines, } \\
\text { thiocarbamates }\end{array}$ & $1-35$ & $\begin{array}{l}\text { Sister chromatid } \\
\text { exchange }\end{array}$ & Negative \\
\hline $71 / 30[44]$ & $\begin{array}{l}\text { Benzimidazoles, organochlorines, } \\
\text { pyrethroids, carbamates, nitroorganics, } \\
\text { dithiocarbamates, phthalimides, } \\
\text { morpholines, organophosphates }\end{array}$ & $2-50$ & Micronuclei & Negative \\
\hline $30 / 31[45]$ & $\begin{array}{l}\text { Carbamates, organophosphates } \\
\text { dithiocarbamates }\end{array}$ & 6 & $\begin{array}{l}\text { Chromosomal } \\
\text { aberration }\end{array}$ & Negative \\
\hline $18 / 20[46]$ & $\begin{array}{l}\text { Captan, diazinon, endosulfan, } \\
\text { malathion, carbofuran }\end{array}$ & $2-25$ & Micronuclei & Negative \\
\hline $23 / 25[48]$ & Organophosphates, carbamates & $0-16$ & $\begin{array}{l}\text { Chromosomal } \\
\text { aberration }\end{array}$ & Positive $(+3.26)$ \\
\hline $20 / 15[49]$ & $\begin{array}{l}\text { Agrimycin, curzate, benlate, cercobin, } \\
\text { folicur, dacostar, lannate, endosulfan, } \\
\text { manzate, recop, microshield, orthene, } \\
\text { nuvacron, pyrimicin, sencor, roundup }\end{array}$ & $10-45$ & $\begin{array}{l}\text { Chromosomal } \\
\text { aberration }\end{array}$ & Negative \\
\hline
\end{tabular}

MCPA: 2-methyl-4-chlorophenoxyacetic acid

comet assay evaluating DNA single strand breaks which showed longest tail length for monocrotophos $2.18 \pm 0.75 \mu \mathrm{m}$ followed by chlorpyriphos with $1.89 \pm 0.63 \mu \mathrm{m}$ whereas dimethoate produced $1.76 \pm 0.54 \mu \mathrm{m}$ length tail on the addition of 10 times higher concentrations.

There have been studies made by comparing different chemical classes of pesticides, dimethoate, and methyl parathion belonging to the organophosphates, propoxur, and pirimicarb from carbamates, and cypermethrin and permethrin from pyrethroids [21]. These chemicals were added in the concentration gradient of 10,50,100, and $200 \mu \mathrm{g} / \mathrm{ml}$. Comet assay performed in the experiments showed that there was a significant increase in tail length with the increase in concentration. Dimethoate showed the highest values at 100 and $200 \mu \mathrm{g} / \mathrm{ml}$ while methyl parathion showed long tails at 10,50 , and $200 \mu \mathrm{g} / \mathrm{ml}$ and its tail intensity was maximum at 100 and $200 \mu \mathrm{g} / \mathrm{ml}$. Propoxur also had showed increased tail length and intensity at 50,100, and $200 \mu \mathrm{g} / \mathrm{ml}$. Pirimicarb showed the maximum tail length at 10 and $200 \mu \mathrm{g} / \mathrm{ml}$ while permethrin and cypermethrin showed an increase at 50 and $200 \mu \mathrm{g} / \mathrm{ml}$. In these studies, however, discrepancies were indicated as the tail length seemed to be independent of the compound and dependent on the concentration whereas for cypermethrin and permethrin this increase was rather dose dependent.

A comparative study comprising of five pyrethroids showed weak genotoxic effects of Cypermethrin, Deltamethrin and Fenpropathrin and no genotoxic effects of Fenvalerate and Permethrin. In-vitro cytokinesis-block micronuclei Assay was conducted on human peripheral leukocytes treated with these pesticides. [22]

In another study, assessing the DNA damage of various pesticides comprising of fungicides like Chlorthalonil, Carbendazim, Fenarimol and Zineb, insecticides like Deltamethrin, Malathion, Malaoxon, Isomalathion, Permethrin, $\mathrm{N}, \mathrm{N}$-diethyl-m-toluamide and Diazinon herbicide as Terbutryn, soil funginant like Methyl isothiocyanate through comet assay showed positive results for all the cases except Carbendazim and Malathion [23]. The concentration of Chlorthalonil was $10 \mu \mathrm{M}$, that of Deltamethrin was $>100 \mathrm{lg} / \mathrm{ml}$, those of Malaoxon and Isomalathion were 25, 75, $200 \mu \mathrm{M}$, Terbutryn was of $100-150 \mu \mathrm{g} / \mathrm{ml}$ concentration, Methyl isothiocyanate was of $<5 \mu \mathrm{g} / \mathrm{ml}$, those of Permethrin, N,N-diethyl-m-toluamide and Diazinon was 0.5-1.0 mM, Fenarimol was of $36 \mathrm{nM}$ and Zineb was used in 50, 100 $\mu \mathrm{g} / \mathrm{ml}$ of concentration.

\section{OCCUPATIONAL EXPOSURE AND ITS ANALYSIS}

The individuals who are involved with the formulations, manufacturing, and spraying of the pesticides are exposed to a mixture of pesticides, their active ingredients as well as the different by-products.

The data on workers working in chemical plants are given in Table 1. In Table 2, data on workers involved in pesticide spraying and exposed to single pesticide are compiled. Data on workers involved in pesticide spraying and exposed to a mixture of pesticide are compiled in Table 3. Data on agricultural workers involved in agriculture works are compiled in Table 4.

\section{REFERENCES}

1. Didla SR, Sairam PG, Chitti S. Assessment of cytotoxic and genotoxic potentials of occupationally pesticide exposed population. Int J Adv Biotechnol Res 2011;2:395-9.

2. Rupa DS, Hasegawa L, Eastmond DA. Detection of chromosomal breakage in the 1cen-1q12 region of interphase human lymphocytes using multicolor fluorescence in situ hybridization with tandem DNA probes. Cancer Res 1995;55(3):640-5.

3. Lieberman AD, Cantu E. Genotoxicity from domestic use of organophosphate pesticides. J Occup Environ Med 1999;41(6):417-8.

4. Sobti RC, Krishan A, Pfaffenberger CD. Cytokinetic and cytogenetic effects of some agricultural chemicals on human lymphoid cells in vitro: Organophosphates. Mutat Res 1982;102(1):89-102.

5. Prabhavathy Das G, Pasha Shaik A, Jamil K. Cytotoxicity and genotoxicity induced by the pesticide profenofos on cultured human peripheral blood lymphocytes. Drug Chem Toxicol 2006;29(3):313-22.

6. Lioi MB, Scarfi MR, Santoro A, Barbieri R, Zeni O, Salvemini F, et al. Cytogenetic damage and induction of pro-oxidant state in human lymphocytes exposed in vitro to gliphosate, vinclozolin, atrazine, and DPX-E9636. Environ Mol Mutagen 1998;32(1):39-46.

7. Ribas G, Surrallés J, Carbonell E, Xamena N, Creus A, Marcos R. Genotoxicity of the herbicides alachlor and maleic hydrazide in cultured human lymphocytes. Mutagenesis 1996;11(3):221-7.

8. González NV, Soloneski S, Larramendy ML. Genotoxicity analysis of the phenoxy herbicide dicamba in mammalian cells in vitro. Toxicol In Vitro 2006;20(8):1481-7. 
10. da Silva Augusto LG, Lieber SR, Ruiz MA, de Souza CA. Micronucleus monitoring to assess human occupational exposure to organochlorides. Environ Mol Mutagen 1997;29(1):46-52.

11. Ennaceur S, Ridha D, Marcos R. Genotoxicity of the organochlorine pesticides 1,1-dichloro-2,2- bis(p-chlorophenyl)ethylene (DDE) and hexachlorobenzene (HCB) in cultured human lymphocytes. Chemosphere 2008;71(7):1335-9.

12. Yoder J, Watson M, Benson WW. Lymphocyte chromosome analysis of agricultural workers during extensive occupational exposure to pesticides. Mutat Res 1973;21(6):335-40.

13. Molinari G, Soloneski S, Reigosa MA, Larramendy ML. In vitro genotoxic and cytotoxic effects of ivermectin and its formulation ivomec on Chinese hamster ovary (CHOK1) cells. J Hazard Mater 2009;165(1-3):1074-82.

14. Cid MG, Matos E. Induction of sister-chromatid exchanges in cultured human lymphocytes by Aldicarb, a carbamate pesticide. Mutat Res 1984;138(2-3):175-9.

15. González Cid M, Matos E. Chromosomal aberrations in cultured human lymphocytes treated with aldicarb, a carbamate pesticide. Mutat Res 1987;191(2):99-103.

16. Rencüzogullari E, Topaktas M. Chromosomal aberrations in cultured human lymphocytes treated with the mixtures of carbosulfan, ethyl carbamate and ethyl methanesulfonate. Cytologia 2000;65(1):83-92.

17. Puig M, Carbonell E, Xamena N, Creus A, Marcos R. Analysis of cytogenetic damage induced in cultured human lymphocytes by the pyrethroid insecticides cypermethrin and fenvalerate. Mutagenesis 1989;4(1):72-4.

18. Suman G, Naravaneni R, Jamil K. In vitro cytogenetic studies of cypermethrin on human lymphocytes. Indian J Exp Biol 2006;44(3):233-9.

19. Barrueco C, Herrera A, Caballo C, de la Peña E. Induction of structural chromosome aberrations in human lymphocyte cultures and $\mathrm{CHO}$ cells by permethrin. Teratog Carcinog Mutagen 1994;14(1):31-8.

20. Jamil K, Shaik AP, Mahboob M, Krishna D. Effect of organophosphorus and organochlorine pesticides (monochrotophos, chlorpyriphos, dimethoate, and endosulfan) on human lymphocytes in vitro. Drug Chem Toxicol 2004;27(2):133-44.

21. Xia Y, Bian Q, Xu L, Cheng S, Song L, Liu J, et al. Genotoxic effects on human spermatozoa among pesticide factory workers exposed to fenvalerate. Toxicology 2004;203(1-3):49-60.

22. Surrallés J, Xamena N, Creus A, Catalán J, Norppa H, Marcos R. Induction of micronuclei by five pyrethroid insecticides in wholeblood and isolated human lymphocyte cultures. Mutat Res 1995;341(3):169-84.

23. Undeger U, Basaran N. Effects of pesticides on human peripheral lymphocytes in vitro: Induction of DNA damage. Arch Toxicol 2005;79(3):169-76.

24. Jablonická A, Poláková H, Karelová J, Vargová M. Analysis of chromosome aberrations and sister-chromatid exchanges in peripheral blood lymphocytes of workers with occupational exposure to the mancozeb-containing fungicide Novozir Mn80. Mutat Res 1989;224(2):143-6.

25. Laurent C, Jadot P, Chabut C. Unexpected decrease in cytogenetic biomarkers frequencies observed after increased exposure to organophosphorus pesticides in a production plant. Int Arch Occup Environ Health 1996;68(6):399-404

26. Kaioumova DF, Khabutdinova LKh. Cytogenetic characteristics of herbicide production workers in Ufa. Chemosphere 1998;37(9-12):1755-9.

27. Garaj-Vrhovac V, Želježić D. Chromosomal aberrations and frequency of micronuclei in workers employed in pesticide production. Biologia 1999;54(6):707-12.

28. Padmavathi P, Aruna Prabhavathi P, Reddy PP. Frequencies of SCEs in peripheral blood lymphocytes of pesticide workers. Bull Environ Contam Toxicol 2000;64(2):155-60.

29. Linnainmaa K. Sister chromatid exchanges among workers occupationally exposed to phenoxy acid herbicides 2,4-D and MCPA. Teratog Carcinog Mutagen 1983;3(3):269-79.

30. Steenland K, Carrano A, Ratcliffe J, Clapp D, Ashworth L, Meinhardt T. A cytogenetic study of papaya workers exposed to ethylene dibromide. Mutat Res 1986;170(3):151-60.

31. Mustonen R, Kangas J, Vuojolahti P, Linnainmaa K. Effects of phenoxyacetic acids on the induction of chromosome aberrations in vitro and in vivo. Mutagenesis 1986;1(4):241-5.

32. Garry VF, Griffith J, Danzl TJ, Nelson RL, Whorton EB, Krueger LA, et al. Human genotoxicity: Pesticide applicators and phosphine. Science 1989;246(4927):251-5.

33. Garry VF, Danzl TJ, Tarone R, Griffith J, Cervenka J, Krueger L, et al. Chromosome rearrangements in fumigant appliers: Possible relationship to non-Hodgkin's lymphoma risk. Cancer Epidemiol Biomarkers Prev 1992;1(4):287-91.

34. Barbosa A, Bonin AM. Evaluation of phosphine genotoxicity at occupational levels of exposure in New South Wales, Australia. Occup Environ Med 1994;51(1):700-5.

35. Titenko-Holland N, Windham G, Kolachana P, Reinisch F, Parvatham S, Osorio AM, et al. Genotoxicity of malathion in human lymphocytes assessed using the micronucleus assay in vitro and in vivo: A study of malathion-exposed workers. Mutat Res 1997;388(1):85-95.

36. Steenland K, Cedillo L, Tucker J, Hines C, Sorensen K, Deddens J, et al. Thyroid hormones and cytogenetic outcomes in backpack sprayers using ethylenebis(dithiocarbamate) (EBDC) fungicides in Mexico. Environ Health Perspect 1997;105(1):1126-30.

37. Calvert GM, Talaska G, Mueller CA, Ammenheuser MM, Au WW, Fajen JM, et al. Genotoxicity in workers exposed to methyl bromide. Mutat Res 1998;417(2-3):115-28

38. Figgs LW, Holland NT, Rothmann N, Zahm SH, Tarone RE, Hill $\mathrm{R}$, et al. Increased lymphocyte replicative index following 2,4-dichlorophenoxyacetic acid herbicide exposure. Cancer Causes Control 2000;11(4):373-80.

39. Páldy A, Puskás N, Vincze K, Hadházi M. Cytogenetic studies on rural populations exposed to pesticides. Mutat Res 1987;187(3):127-32.

40. Rita P, Reddy PP, Reddy SV. Monitoring of workers occupationally exposed to pesticides in grape gardens of Andhra Pradesh. Environ Res 1987;44(1):1-5.

41. Nehéz M, Boros P, Ferke A, Mohos J, Palotás M, Vetró G, et al. Cytogenetic examination of people working with agrochemicals in the southern region of Hungary. Regul Toxicol Pharmacol 1988;8(1):37-44.

42. Högstedt B, Kolnig AM, Mitelman F, Skerfving S. Cytogenetic study of pesticides in agricultural work. Hereditas 1980;92(1):177-8.

43. Gómez-Arroyo S, Noriega-Aldana N, Osorio A, Galicia F, Ling S, Villalobos-Pietrini R. Sister-chromatid exchange analysis in a rural population of Mexico exposed to pesticides. Mutat Res 1992;281(3):173-9.

44. Bolognesi C, Merlo F, Rabboni R, Roggieri P, Reggiardo G, Abbondandolo A. Genotoxic risk from occupational exposure to pesticides in floriculture. Clin. Chem 1995;41(12):1919-21.

45. Hoyos LS, Carvajal S, Solano L, Rodriguez J, Orozco L, López Y, et al. Cytogenetic Monitoring of Farmers exposed to pesticides in Colombia. Environ Health Perspect 1996;104 Suppl 3:535-8.

46. Davies HW, Kennedy SM, Teschke K, Jenny P, Quintana E. Cytogenetic analysis of South Asian berry pickers in British Columbia using the micronucleus assay in peripheral lymphocytes. Mutat Res 1998;416(1-2):101-13.

47. Au WW, Sierra-Torres CH, Cajas-Salazar N, Shipp BK, Legator MS. Cytogenetic effects from exposure to mixed pesticides and the influence from genetic susceptibility. Environ Health Perspect 1999;107(6):501-5.

48. Antonucci GA, de Syllos Cólus IM. Chromosomal aberrations analysis in a Brazilian population exposed to pesticides. Teratog Carcinog Mutagen 2000;20(5):265-72.

49. Grégio D'Arce LP, Cólus IM. Cytogenetic and molecular biomonitoring of agricultural workers exposed to pesticides in Brazil. Teratog Carcinog Mutagen 2000;20(3):161-70. 